\title{
Margaret McCartney: Getting the abstract in perspective
}

\author{
Margaret McCartney general practitioner
}

Glasgow

There's a conference on! Who could have guessed? On 1 June we had the front page headline, "Cancer blood test hailed as "holy grail."” On 2 June we had, "NHS cancer patients 'failing to be correctly monitored."”2 On 3 June, joy of joys: "GPs handing out too many antibiotics harms cancer survival chances." ${ }^{3}$ In case that last one hasn't treated my colleagues' hypotension enough, here's a choice quote: "People see their GP and the GP thinks, 'Oh my goodness it's a cancer patient, they need antibiotics."”

Let us regroup. This is a meeting of the American Society of Clinical Oncology (ASCO), where research is transmitted to the world through press briefings, abstracts, and talks. We live in a world where completed, peer reviewed research is shared ahead of publication under embargo, to allow journalists time to check facts and produce accurate coverage. Yet works in progress are released to global fanfare, having been presented only in abstract form, without peer review-making it hard to check the researchers' workings and uncertainties.

Let's take the cancer blood test "holy grail" article, ${ }^{1}$ which is a story of several abstracts. ${ }^{4-7}$ A blood test, performed prospectively in people with cancer and people in a control group, can find a DNA marker with a high degree of sensitivity in patients with cancer but has varying, and not very high, specificity (from 56\% upwards). This was not a study testing any intervention to see whether deaths could be delayed, and many of the researchers are employed by, and own shares in, the company making the test. As such, one newspaper's suggestion of the test being available on the NHS "within five years" " seems rather optimistic.

Works in progress are released to global fanfare, having been presented only in abstract form

Then there's the story of NHS cancer patients "failing to be correctly monitored." ${ }^{2}$ How long should people who have been treated for different types of cancer be followed up by an oncologist? It's a great question, but we have only an abstract summarising research on a North American database. The research seems to have found wide variation in how long people are followed up for in the United States-in a very different healthcare system from the NHS - and that some cancers are more likely to recur than others. It is clearly not a study showing that changing current practice will decrease the risk of death. ${ }^{8}$ However, Joyce Robins, of the UK advocacy group Patient Concern, is quoted as saying that it is "terrifying that cancer patients are being abandoned like this."

Moving on, we have the story of how "GPs handing out too many antibiotics harms cancer survival chances." This last one is based on a retrospective data analysis that showed an association between patients with metastatic disease being treated with antibiotics and the earlier progression of disease and death. ${ }^{9}$ The abstract does not mention who gave the antibiotics or why: perhaps there are other reasons why patients who receive more antibiotics do less well.

All of this research is interesting and has the potential to improve healthcare. A proposal from the Academy of Medical Sciences, ${ }^{10}$ to "traffic light" press releases to classify them in terms of peer review and how relevant the research is to people, may help; but my question is whether it is useful for the public or professionals to publicise or use press releases of conferences for conference abstracts at all.

Competing interests: See www.bmj.com/about-bmj/freelance-contributors/margaretmccartney.

Provenance and peer review: Commissioned; not externally peer reviewed.

1 Bodkin $\mathrm{H}$. "Holy grail" blood test could detect cancer long before tumours develop. Daily Telegraph 31 May 2018. https://www.telegraph.co.uk/science/2018/05/31/holy-grail-bloodtest-could-detect-cancer-long-tumours-develop/.

2 Glenza J. NHS cancer patients "failing to be correctly monitored." Guardian 2 June 2018. https://www.theguardian.com/society/2018/jun/02/nhs-cancer-patients-failing-to-becorrectly-monitored?CMP=Share AndroidApp Tweet.

3 Bodkin H. GPs handing out too many antibiotics harms cancer survival chances. Daily Telegraph 3 June 2018. https://www.telegraph.co.uk/science/2018/06/02/gps-handingmany-antibiotics-harms-cancer-survival-chances/.

4 Liu MC, Maddala T, Aravanis A, et al. Breast cancer cell-free DNA (cfDNA) profiles reflect underlying tumor biology: the Circulating Cell-Free Genome Atlas (CCGA) study. ASCO Meeting Library (presented 2 June 2018). https://meetinglibrary.asco.org/record/162641/ abstract.

5 Oxnard GR, Maddala T, Hubbell E, et al. Genome-wide sequencing for early stage lung cancer detection from plasma cell-free DNA (cfDNA): the Circulating Cancer Genome 
Atlas (CCGA) study. ASCO Meeting Library (presented 4 June 2018). https://meetinglibrary. asco.org/record/160036/abstract.

6 Klein EA, Hubbell E, Maddala T, et al. Development of a comprehensive cell-free DNA (cfDNA) assay for early detection of multiple tumor types: the Circulating Cell-free Genome Atlas (CCGA) study. ASCO Meeting Library (presented 4 June 2018). https://meetinglibrary. asco.org/record/161733/abstract.

7 Swanton C, Venn O, Aravanis A, et al. Prevalence of clonal hematopoiesis of indeterminate potential (CHIP) measured by an ultra-sensitive sequencing assay: exploratory analysis of the Circulating Cancer Genome Atlas (CCGA) study. J Clin Oncol 2018;36 (suppl; abstr 12003). http://abstracts.asco.org/214/AbstView_214_213439.html.

8 Dood R, Zhou Y, Armbruster SD, et al. Defining survivorship and surveillance with evidence. ASCO Meeting Library (presented 2 June 2018). https://meetinglibrary.asco. org/record/162331.
9 Tinsley N, Zhou C, Villa S, et al. Cumulative antibiotic use and efficacy of immune checkpoint inhibitors in patients with advanced cancer. ASCO Meeting Library (presented 4 June 2018). https://meetinglibrary.asco.org/record/159158/abstract.

10 Academy of Medical Sciences. Enhancing the use of scientific evidence to judge the potential benefits and harms of medicines. June 2017. https://acmedsci.ac.uk/file-download/ 44970096.

Published by the BMJ Publishing Group Limited. For permission to use (where not already granted under a licence) please go to http:/group.bmj.com/group/rights-licensing/ permissions 